\title{
Growth of Rural Retailing in India with Reference to Kolhapur District
}

\author{
Author- Prof.Pravin Jadhav \\ Asst.Professor., Department of Management Studies. \\ DKTE Textile \& Engg. Inst., Rajwada,Ichalkaranji-416115, Dist-Kolhapur, Maharashtra, India \\ Co-author- Prof. Shailendra Patil \\ Asst.Professor., Department of Management Studies, DKTE Textile \& Engg. Inst. \\ Rajwada,Ichalkaranji-416115, Dist-Kolhapur, Maharashtra, India
}

\begin{abstract}
-
The aim of the study is to identify the growth of rural retailing in India with reference to Kolhapur district. A decade ago, the rural market was more unstructured and was not a prioritized target location for corporate. There were no innovative approach and advertisement campaigns. A distribution system did exist, but was feeble. Illiteracy and lack of technology were the other factors leading to the poor reach of merchandise and lower level of awareness amongst villagers. Gradually, corporate realized that there was saturation, stiff competition and clutter in the urban market, and a demand was building up in rural areas. Seeing the vast potential of $70 \%$ of Indians living in rural areas, they started focusing on these unexplored, high-potential areas. In India totally there are 5, 70,000 villages and nearly 60 percent of the rural income comes from agriculture. As a result, retail outlets have sprung up in practically all the villages that store merchandises of various brands and categories. To attract the customers, rural retailing requires separate retailing approach for the retailing mix elements include, Merchandise, Cost, Location and Advertisements which could be formulated after studying the market carefully. Merchandise itself might require modifications due to different nature of population, pricing have to be carefully designed since rural consumers unlike their urban counterparts spend less on consumer merchandise, location have to be decided for easy accessibility and promoting the merchandise to encourage the sales. Retailing Strategy is affected by various factors like Type of merchandise (Durable or non-durable), profile of target market, and facilities available for using retailing mix etc.
\end{abstract}

Keywords: Retailing approach, Rural Retailers, Merchandise, Cost, Location, and Advertisement.

DOI: $10.7176 / \mathrm{EJBM} / 12-13-05$

Publication date:May $31^{\text {st }} 2020$

\section{Introduction}

More than 617 million Indians (70.3\%) of Indians population live in rural areas. They are distributed over a mindboggling 6, 30,000 villages. The large amorphous mass of rural India is verily a marketer's delight. Data generated by National Applied Council of applied Economic Research (NCAER) show that not less than 70\% of all Indian sales in some merchandise categories come from rural India. Unfortunately, the gigantic market is being addressed as a spill off of the urban oriented communication. Be that as it may, some companies have hit the rural dirt tracks with some imaginative campaigns. So this made us to study on the effective retailing approach used by the rural retailers.

\section{Review of Literature}

According to Nancy J. Miller, Assistant professor in textiles and clothing, Use business approach other than cost or quality differentiation. Consumers who are concerned with cost are less likely to limit their shopping to local stores.

According to Epstein, 1992, in today's fast changing retail environment the retail manager must utilize effective planning if the enterprise is to be a success. To be successful in the $90 \mathrm{~s}$, retailers must be good at everything; they must have a good merchandising concept, execute it effectively, and operate it in a spectacular manner. To accomplish this retail manager must develop and utilize an effective plan for the business Therefore the rural markets are much larger when compared to the urban market in terms of population and number of households. In other words, for every consumer in urban area, there are three of them in rural areas. Nearly one half of the countries national income is generated here. These rural areas are considered to be the back bone of Indian economy and full of opportunity and scope for rural market in India is vast and scattered and offers a plethora of opportunities. Thus companies are finding rural markets increasingly attractive. Rural markets are not exploited completely and yet to be explored.

According to Professor Bernard Codner, Director of the Institute of Retail Management at California State University, the successful retail merchant must know his/her customer and develop a retailing mix to serve that customer's needs. He stated that "Whether lavish or plain, retail stores have to clearly identify their niche in the 
market. Retailers must know exactly what kind of customer they are trying to attract." (Epstein, 1992). The best way for a merchant to discover what customers want is to ask them (Baird, 1988).

It is important to note from Gruidl and Kline (1992) in his article, "What Happens When a Large Discount Store Comes to Town?" Effective pricing is a strategy that will increase in importance during the decade of the 90 's. Customers are looking for either the lowest cost or the highest quality that they can find. The successful merchant must determine which market is to be served. Other customers will want very low costs on all of the goods they purchase. Retail merchants must either control costs so they can offer lower costs profitably, or improve service and the quality of goods to survive. And also he suggested that the small merchant improve customer service in order to compete with the large discount store. Among those services that they suggested as having been proven effective in gaining and retaining customers were: delivery, alterations and installations, adjusting store hours, improving the handling of customer complaints, liberal return policies, gift certificates, trial purchases, special sales for regular customers, mail and telephone orders, bridal registries, interior design services, ticket outlets, parking, water fountains, rest rooms, restaurants, babysitting, fitting rooms, shopping bags and general information

William Oykema (1991), in his article, "Successful Retailers Display High Shelf Respect," stated that the one method available to retailers to differentiate themselves from their competition and to create an image in the minds of their customers is advertisement. The particular needs of the market niche selected will dictate the method of advertisement that is utilized.

According to Kumar (2002), marketers have to adopt a strategy that appeals individually to the rural audience. Changes must be made in retailing mix elements such as cost, location, merchandise and advertisement

According to Satterthwaite (2001), for urban retailing to be successful, there must be interaction between the commercial and social activities

Kaur Manpreet (2013) attempted to find out the various initiatives taken by HUL to reach the rural consumer. Hindustan Unilever is the pioneer and largest player in India's FMCG market. HUL was the first company to step into the Indian rural retailing. HUL started its first effort towards going rural 1960's onwards, through indirect coverage of accessible rural market through its urban network stockiest and distributors. HUL proactively engaged in rural development in 1976 with Integrated Rural Development Programme in Etah district of Uttar Pradesh. In 1990, HUL launched 'Operation Streamline' for distribution of merchandise to inaccessible rural markets with High potential using unconventional transport like bullock carts, tractors and bicycles and appointed rural distributors and star sellers. In 2000, HUL started Project Shakti to reach inaccessible low potential rural markets. This project has reached 100,000 villages. HUL embarked upon Project Samuriddhi in 2003 to create sustainable villages in Dadra and Nagar Haveli. Today HUL's merchandise touch the lives of two out of every three Indians. Kotni VV Devi Prasad (2012) proposed to undertake this study to find out various ways to tap the potential rural markets. The main aim of this study was to observe the potentiality of Indian Rural Markets and finding out various problems are being faced by rural markets. This paper attempted to provide a brief literature on rural retailing and finally offers policy recommendations for better performance of rural markets by adopting SWOT analysis matrix to rural markets.

Objectives of the study:

The primary objective is to identify the growth rural retailing in India with reference to Kolhapur district. And the secondary objectives are

- To provide suggestions in order to make the rural retailing a success.

- To identify the kind of merchandise the rural retailers sells.

- To study the suppliers' influence towards the retailers in retailing.

\section{Importance of the study}

Over the years, the attitude and lifestyle of rural folk has changed due exposure through Technology and increase in literacy level. Also, consumers are becoming brand loyal.

- The rural Indian population is large and its growth rate is also high which shows that the Indian rural market has great potential which needs to be captured.

- The purchasing power in rural India is on steady rise and it has resulted in the growth of the rural market.

- The rural audience has matured enough to understand the communication developed for the urban markets Television has been a major effective communication system for rural people and, as a result, companies can identify themselves with their advertisements. Socio- economic changes (lifestyle, habits and tastes, economic status)

With the constant invasion of corporate, the rural customer has started taking in "what was educated to him", the media, newspaper, cable, IT developments, mobiles have led to increased awareness. Besides, due to increase in purchasing power and literacy level of a section, the rural consumer has become more receptive. S/he is highly influenced by "word of mouth" and has started looking at value for money. 
The changing market scenario, introduction of new merchandise, increasing awareness amongst customers and the overall development in rural sector, required a change in corporate retailing approach, and this was done.

This study will help all the rural retailers to cope up with the current market by adopting the right retailing approach to the consumers.

\section{Research Methodology}

In this study, we took Descriptive Research design to realize the behavior pattern of the rural retailers. Because of the short period of time, Convenience sampling Design is taken and totally 100 retailers are being surveyed in Kolhapur district for this study. Primary data is taken from the rural retailers with the help of structured questionnaire framed with closed type of questions. And the Secondary data is also collected from the journals, books and internet for the further reference. The tools used for analysis is Hypothesis testing method and percentage analysis method to represent the data in chart appearance.

\section{Hypothesis}

This made the need for studying rural retailers and their approach for retailing successfully. And in the study, we are setting the hypothesis as

HO: There is no significant relation between experience of retailers and retailing strategy of retailers.

H1: There is a significant relation between experience of retailers and retailing strategy of retailers.

HO: There is no significant relation between type of merchandise and retailing strategy of retailers.

H1: There is a significant relation between type of merchandise and retailing strategy of retailers.

HO: There is no significant relation between supplier's influence and retailing strategy of retailers.

H1: There is a significant relation between supplier's influence and retailing strategy of retailers.

\section{Findings}

It is found out of the study that the credit facility \& Building relations $(30 \%)$ plays a vital role by the rural retailers to attract the rural customers which are shown in chart 1 . It is also inferred that the source of merchandise is mostly from manufacturers and the agriculturalist (30\%) where these retailers get merchandise which is in chart 2. And from the study it reveals that there is high influence (37\%) from the suppliers/distributors and which is shown clearly in chart 3. The study also points out that FMCG (24\%) and clothing's (23\%) are mostly handled by the rural retailers which are also clearly displayed in chart 4.

Table 1

\begin{tabular}{|c|l|c|c|c|}
\hline S. No & \multicolumn{1}{|c|}{ Hypothesis } & $\begin{array}{c}\text { Table } \\
\text { value }\end{array}$ & $\begin{array}{c}\text { Calculated } \\
\text { value }\end{array}$ & Result \\
\hline 1. & $\begin{array}{l}\text { There is no significant relation between experience of retailers } \\
\text { and retailing strategy of retailers. }\end{array}$ & 21.026 & 23.1944 & Rejected \\
\hline 2. & $\begin{array}{l}\text { There is no significant relation between type of merchandise } \\
\text { and retailing strategy of retailers. }\end{array}$ & 31.410 & 27.5111 & Accepted \\
\hline 3. & $\begin{array}{l}\text { There is no significant relation between supplier's influence } \\
\text { and retailing strategy of retailers. }\end{array}$ & 16.919 & 18.3333 & Rejected \\
\hline
\end{tabular}

Table -1 represents that,

1. There is a significant relationship between experience of the rural retailer and the retailing strategy used by them. Because they knows about the customer's background very well, since they are in the same field.

2. There is no significant relationship between Kinds of merchandise and the retailing strategy used by him. Because of the little awareness level, the type of merchandise won't affect that much and they won't bother about the specific merchandise/brand, if that is not available then they may choose other merchandises/brands.

3. There is a significant relationship between supplier's/distributor's influence and the retailing strategy used by him. Because he is only a link between supplier/distributor and he has to accept/adopt whatever they orders. And the full control lies with them, or otherwise they may not supply the merchandise.

\section{Suggestions}

At present, the rural customer's literate level is improving vastly. So the retailers may consider for the high tech services like computer billing system in their shops. Currently all the multinational companies' eyes are in the retail field that to in rural areas. To compete with them the existing rural retailers they have to change their strategy because the large scale industries now target on rural areas, because of land value, vast market and untapped resources.

- The efficient retailing and distribution system is necessary to reach ultimate consumer in the quickest time possible at minimum cost.

- The communication systems must be developed to make it appropriate to rural market. If not possible, 
communication must be in regional language.

- Public weighing machines one in each rural market to ensure correct weight measuring machine for farm and non-farm arrivals. Storage god owns are also required.

- For storage facilities the government should not depend on private agencies to store food grains (National commission on Agriculture recommended).

- $\quad$ The existing retailing staff must be increased and adequate training must be given.

- The proper packaging technology must be improved.

It is time for the rural retailers to use this opportunity and also they can go for some contracts with them to supply the merchandise.

The customers in rural are affected by the modern trends and fashions, they may opt to go for those merchandise. Each and every retailer may concentrate on the profile of each household and then accordingly they can go for the suitable approach.

\section{Conclusion}

In modern days, each and every industry is concentrating on rural areas because the urban areas are almost saturated. And the rural areas are having scope to develop and this is the right time for the retailers to enrich their market. The customer's migration is more towards urban retail and this is one of the major drawbacks of the rural retailers. To overcome these they have to adopt some of the retailing approach to cover the customers and retain their existing customers. They can also move towards some modification on merchandise, cost, location and advertisement to compete in this competitive rural market yet potential market.

\section{References}

1. Baba Ganakumar P. Reinforcing rural retail mix in festival seasons by urban retailers, 2002.

2. Baird, Barbara. Snaring Shoppers; Owners of Small Retail Stores Cultivate a Clientele All Their Own Using Personalized Service and a Smile. Los Angeles Times, 23, December, 1988.

3. Epstein, Stephen H. Discount Merchandiser February, 1992, 88-89.

4. Gade Michael, Salerno R. Technology and the Small Retailer. Discount Merchandiser December, $1990,16$.

5. Gruidl J, Kline S. What Happens When a Large Discount Stores Comes to Town? Small Town 23. MarchApril, 1992.

6. Hernandez T, Jones K. Downtowns in transition: emerging business improvement area approach, International Journal of Retail \& Distribution Management. 2005; 33:789-805.

7. Miller Nancy J, Kean Rita C. Factors contributing to in shopping behavior in rural trade areas: Implications for local retailers. Journal of Small Business Management. 1997a; 35(2):80-94.

8. Miller Nancy J, Kean Rita C. Reciprocal exchange in rural communities. Psychology \& Retailing 1997b; 14(7):637-661.

9. Oykema W. Successful Retailers Display High Shelf, October, 1991.

10. Katiyar Ruchi, Prahalad CK. Rural retailing: Challenges, Opportunities \& Approach, 2000.

11. Kaur Manpreet. Rural Retailing: A Case Study on Hindustan Unilever Limited International Journal of Applied Research and Studies, 2013, 2(6).

12. Kotni VV Devi Prasad. Prosoects and Problems of Indian rural Markets Zenith International Journal of Business Economics and management Research. 2012, 2(3).

13. Misra SK. Indian Economy, Himalaya Publishing House, 18th Edition, New Delhi, 2000, 739.

14. Rajendhiran. N, Saiganesh S, Asha P. Rural Retailing-A critical Review 